\title{
The Cost of a Calling? Clergywomen and Work in the Church of England
}

Greene, A \& Robbins, M

This article is published by Wiley. The definitive version of this article is available at: https://onlinelibrary.wiley.com/doi/abs/10.1111/gwao.12101

\section{Recommended citation:}

Greene, A.M. and Robbins, M. (2015), 'The cost of a calling? Clergywomen and work in the Church of England', Gender Work and Organization, Vol.22, No.4, pp.405-420. doi: 10.1111/gwao.12101 


\title{
The Cost of a Calling? Clergywomen and work in the Church of England.
}

\begin{abstract}
This article explores the work of clergywomen in the Church of England within an analysis of the Church as a gendered organisation. We highlight the sex discrimination they often face, at the same time as satisfaction with their work and the need to follow their calling regardless of the difficulties. This is explained through an analysis of the significance of religious calling and the requirement for 'sacrifice' on their ability to endure their work and to challenge discriminatory treatment.
\end{abstract}

Keywords: clergywomen, gender practices, sex discrimination, vocation, calling, sacrifice.

\section{Introduction}

This article presents an employment relations analysis of the work experiences of a small group of clergywomen within the Church of England (CofE), which we argue is a fundamentally gendered organisation. While women were able to be ordained as priests in 1994, it was not until November 2014 that the General Synod finally allowed women bishops, after rejection of previous votes on this issue as recently as 2012. The first consecration and appointment of a woman bishop occurred in January 2015. We begin by detailing the work context of the CofE, placing this within a consideration of the 'standard employment relationship' and establishing its gendered characteristics. We specifically draw on Peyton and Gatrell's (2013) concept of the 'sacrificial embrace' as a useful way to understand experiences of clergy work. However, we look specifically at the way in which this 'sacrificial embrace' is firstly gendered and has gendered consequences, and secondly has effects on experiences of the clergy 'employment relationship' and of the role of conventional employment relations actors such as trade unions. Our study is then outlined, describing the sample of interviewees, research questions, methods employed and our methodological approach. We then use our empirical findings to bring the picture of gendered work within the CofE to life. We conclude that the religious calling of our interviewees has significant consequences for their willingness to accept difficulties and their ability to challenge discrimination, highlighting the particular gendered implications of their 'sacrificial embrace'.

\section{Clergy work and the employment relationship}

The work of parish clergy possesses some characteristics of a standard employment relationship for example regular pay (stipend), recruitment and selection processes and training, and formalised disciplinary procedures. Latest statistics show that there are 10948 CofE clergy of whom 8007 are stipendiary (Archbishops Council, 2013). We focus on stipendiary parish clergy because they represent the closest situation to a standard employment relationship primarily because they are paid and because they are directly appointed to posts within the CofE. It should be noted that $23 \%$ of CofE clergy are unpaid, or what is termed 'self-supporting clergy' and additionally there are 1018 chaplains who are employed by the armed services, hospitals, prisons, schools, and higher and further education. Neither of these last two categories is the subject of our research because they are not paid for what they do, or they are formally considered as employees of other organisations, moving them away from a situation where the CofE could be considered to be their 'employer'.

Considering trade union representation as a criterion of standard employment status, clergy in the UK are organised by the trade union Unite, within its Faith Organisations Subsectori. Latest data indicates that there are 1180 active members of the subsectorii, split between 18 religious denominations, of which $51 \%$ are CofE clergy. Membership is low within the CofE; the best estimates gained by cross-referencing union and CofE statistics indicating a density of between 5 and $8 \%$, compared with overall UK private sector density of $14 \%$ (BIS, 2013). The proportion of men and women in membership is similar to the overall gender breakdown of CofE clergy ( $73 \%$ and $27 \%$ compared to $77 \%$ and $23 \%$ ): there does not seem to be an 
increased propensity for either clergy men or women to be union members. In 2012, the union set up a branch association for the CofE called the Church of England Clergy Advocates (CECA) in order to represent CofE members' interests. The union has no collective bargaining agreements or rights of collective representation for its CofE members. However it does provide support for individual cases brought by clergy members; a regional organisation of around 60 lay representatives (though none of these are CofE clergy); and a 24 hour help and support telephone line. It also seeks regular meetings with, representative bodies of the CofE such as the Ministry Division of the Archbishops' Council; however this is not established within any kind of recognition agreement.

A decade ago the work of CofE clergy was notable for its lack of policies and procedures. This has changed with the introduction of Common Tenure (CT), applied to all new appointments and existing fixed term appointments after 31 January 2011 (Church of England, 2014). CT gives parish clergy a statement of particulars which formally sets out in writing, rights to a fairly extensive package of employment terms and conditions, including paid leave (including maternity) and time off. It also gives a high measure of job security to clergy, abolishing fixed term posts (except in specific limited circumstances), so that most clergy cannot be required to leave a parish until they resign or retire without due process and/or compensation. The CofE has not taken the route of granting employment status, rather what is termed 'preserving officer holder status in the $21^{\text {st }}$ century' (IDS, 2011). Despite this, CT is still a significant progressive step, covering many areas that would normally be protected under employment law.

However, many features of clergy work mean that it stands outside of a standard employment relationship. One aspect relates to remuneration. Unlike a wage, a stipend is supposed to be merely 'adequate for clergy to discharge their duties without undue financial anxiety' (Central Stipends Authority, 2013: 1), in other words it does not have a relationship to hours worked. The remuneration package also includes provision of a tied parish house, non-contributory pension, plus provision for parish-related expenses. This reflects the fact that the relationship of clergy and the CofE is not like that with a conventional employer. Indeed fundamentally the appointment of clergy is held as a spiritual matter of 'office holding for God', with no intention to create legal relations (Cranmer, 2012). Despite a number of legal challenges over the last decade, UK parish clergy are not considered employees and are therefore not covered by protections of employment law. This situation is currently in flux, demonstrated by the 2013 employment appeal tribunal ruling in Reverend Mark Sharpe V Diocese of Worcester, establishing that the fact that the appellant was an 'officeholder' should not have automatically led to a ruling that he was not a 'worker', opening up the way for future employment tribunal applications. However until such a case sets a precedent, CT procedures only offer quasi-legal rights for clergy. Most notably, they are not afforded protection from anti-discrimination legislation within the Equality Act 2010, the significance of which we now go on to discuss.

\section{Clergy work as gendered work in the CofE}

The basis on which the ordination of women was passed in the CofE in 1994 means that theirs is a work situation unlike any other in the UK because, as Bagilhole (2003) argued a decade ago, it is one where direct sex discrimination is formally permitted. In order to accommodate those who were opposed to the ordination of women on theological grounds, the Act of Synod was developed. This set out the Theology of the Two Integrities, existing side by side; one integrity accepting, and the other integrity not accepting, the ordination of women. Under this, a clergywoman could be banned from ordinary duties; the appointment of a duly ordained woman to a post could be prohibited on grounds of her sex; and provision was created for ministering to those parishes opposed to women's ordination, thus institutionally accepting discrimination against women ${ }^{\text {iii. }}$. The legislation emerging from the latest vote in November 2014, while moving away from 
laying down formal provisions, still offers safeguards for opponents, thus arguably leaving significant avenues for continued institutional discrimination ${ }^{\text {iv }}$.

There has been a steady increase in the numbers of women since 1994, and they now account for $23 \%$ of those ordained as full time stipendiary clergy (Archbishops Council, 2013). The level of stipend for each kind of post is set centrally, thus formally there is not a gender pay gap within the CofE. However previous research (Bagilhole, 2006; Roberts et al, 2006) found that women were significantly more likely to hold unpaid positions than men. Notably, this is no longer so starkly the case with latest figures indicating that $47 \%$ of such posts are held by men (Archbishops Council, 2013). However until the latest vote there was vertical segregation within the CofE with the closing off to women of the senior role of bishop- a veritable 'stained glass ceiling' (Sullins, 2000). This was still the situation for the clergywomen in our research study. Even in those senior positions open to them (archdeacons, cathedral canons and clergy), women account for only $11 \%$, a significant improvement on nearly a decade earlier of only $4 \%$ but still reflecting a very maledominated hierarchy (Archbishops Council, 2013).

Personal witness accounts from clergywomen (for example Green $(2009,2011)$ Furlong (1998); Dowell and Williams (1994)), have detailed the discrimination faced by and the 'passive tolerance' which is often felt to be the predominant experience of women priests. Furthermore, beyond direct sex discrimination, clergy work in the CofE is also implicitly gendered. As Green (2011: 17) claims, 'an institution that is steeped in a culture and world view that have long been exclusively male and in customs and rites that have been...maleled and sanctioned and controlled by men'. Debates around the ordination of women bishops encapsulate divisions within the CofE regarding women, arguably continuing to support the salience of the 'doctrine of taint' where women priests are viewed as 'untouchable' and 'polluting' by those who hold a theological opposition (Bagilhole, 2006: 364). Page's work provides a rare example of recent academic research on clergywomen in the UK. Her analysis highlights how 'women are negotiating a discriminatory terrain at many different levels' (Page, 2012: 1), and she explores the negotiation of the clergywomen's sacred roles as 'profane' bodies within Christian theology (2011), the effects of motherhood on priestly identity and liturgical practice $(2011,2012)$ and women's embodiment issues particularly involving clerical dress as an exclusionary mechanism (2014). Therefore, while there is now arguably much less overt and direct sex discrimination in many organisations (Powell et al, 2009), we argue that the CofE provides an example of a contemporary 'inequality regime' (Acker, 2006: 443) involving gendered practices, processes, actions and meanings.

The lack of legal employment rights discussed earlier is therefore significant because CofE clergywomen are noteworthy in the UK amongst professional occupations in not being able to directly utilise the Equality Act 2010. For example even though members of the armed forces do not have the protection of large amounts of employment law, they are covered directly by the Equality Act. CT documentation (Annex B on ecclesiastical appointments) references the Equality Act and its provisions; however guidance documents encapsulate the difficulties inherent to its application within internal Church legislation:

The application of the Act to clergy offices is not straightforward. This is because the legal categories of workers dealt with by the Act are... tailored to the secular sphere and do not reflect the particular characteristics of some ecclesiastical offices (Church of England, 2013a).

In the end it is left to a 'matter of policy care' and a suggestion that 'an equitable approach would be to treat all clergy appointments for practical purposes, as if they were subject to the Act'. Notably there is no compulsion - clergywomen cannot bring a legal claim against the direct discrimination they experience with regard to appointments where a theological objection is raised to them as women, let alone some of the wider indirect discrimination and more informal practices that our study goes on to illuminate. 


\section{The central place of vocational calling}

Clergy work has a religious calling at its core. Clergy 'believe that their physical, intellectual and emotional selves are permanently claimed for the service of God' (Peyton and Gatrell, 2013: 52). Faith, religion and God do not commonly feature within employment relations or organisation studies research, although Bell et al (2012) provide a useful summary of the growth of interest in organisational spirituality in the critical management field. Likewise, the work of those in religious occupations or employment relations actors in these contexts is not commonly studied. Nigel Peyton and Caroline Gatrell's (2013) book Managing Clergy Lives: Obedience, Sacrifice, Intimacy has proved particularly useful for our analysis. Their research involved in-depth qualitative interviews with 46 parish clergy in the CofE, which included 14 women. They look at the central question of why clergy remain committed to their ordination vows despite the serious pressures of ministry and the overall decline of the Church and public Christianity in the UK. They argue that ordination vows necessitate a commitment to a life-long 'sacrificial embrace', governing all aspects of priestly lives (p100). It involves 'the embracing of personal sacrifice, and the governance of body and soul... underpinned by a theological and ministerial rationale, and ultimately an eternal dimension' (p86). The 'embrace' is important, because it inherently involves choice and acceptance of this sacrifice. While aspects of the employment relationship are not a central part of their analysis, they comment that clergy accept an 'accumulative opportunity cost' where expectations of usual work and career rewards are sacrificed in the pursuance and living out of their ordination commitment to God (p118). In our analysis, we argue that this 'sacrificial embrace' has particular and more difficult consequences for clergywomen within the gendered context of the CofE.

Peyton and Gatrell (2013: 90-91) do make brief reference to the gendered nature of the sacrificial embrace, but their analysis does not have this at the heart of their argument. In contrast, our analysis connects with the body of literature within the broad organisation studies field that has identified 'sacrifice' as a particular experience of women when they take on authority roles in the place of men. A key reference point is those writers who draw on feminist philosophers such as Luce Irigaray and Julia Kristeva to inform their work. For Irigaray, female subjectivity is shaped by women sacrificing their sense of difference from the male norm (see Yeng, 2014; Fotaki et al, 2014 and Butler, 2006). For Kristeva, women have only the choice to live as male constructions or be found wanting - they have to sacrifice their feminine qualities in order to assimilate (see Hopfl and Matilal, 2007; Hopfl, 2000). Commonly notions of sacrifice have been used to characterise the work of female-dominated professions such as nurses (see Pank, 2005). However there is an implicit line from these philosophical writings to analysis of those exploring the experience of women working and coping with working in male-dominated contexts (e.g. Puwar, 2004; Bagilhole, 2002; Butler, 1990, 1993; Powell et al, 2009; Simpson, 2003; Wacjman, 1998) which clearly includes the CofE. Given the centrality of sacrifice to clergy work, exploring the ways that this plays itself out for our interviewees as clergywomen has become a core analytical theme.

\section{The Research Study}

We draw on qualitative interviews conducted with 21 women holding or having held stipendiary posts within the CofE. In addition, we interviewed the national officer and a lay representative from the trade union Unite (both women). The interviews ranged in length from an hour and a half to three hours, and were recorded and transcribed. Our initial access was through the union, and half of the interviewees were contacted through an email approach from the national officer of union. The other half was gained as a result of snow-balling on from that sample, and some through personal contacts of the authors. The age range of our sample was between 29 and 63 years, in proportion to the overall population of clergywomen and all interviewees were white, reflecting the fact that $97 \%$ of stipendiary CofE clergy are white (Archbishops Council, 2013). Over half of our interviewees had dependent children under 18 years old at some point 
during their ministry, and five of these were single parents. Two thirds of our interviewees had been ordained for ten years or more and included four who were ordained in the 'first wave' in 1994. We refer to the interviewees by pseudonyms (see Table 1 for details).

\section{INSERT TABLE 1 HERE}

We asked our interviewees to think specifically about being a priest from the perspective of work and the employment relationship and explored a variety of issues including: their calling; previous work experiences; selection and training experiences; reflections on work-life balance; job satisfaction; relationships with employment relations actors such as trade unions, and those acting in 'management' roles within the Church; and experiences of gender discrimination. The research was informed by a feminist methodology with a focus on allowing them to voice their own perspectives, interpretations and experiences. The majority of interviews were conducted in the homes of the clergywomen, and so we shared the experiences of Peyton and Gatrell's (2013: 34) 'ethnography at the vicarage'. They discuss the strength of 'critical distance' where there is an insider and an outsider involved in research (Peyton and Gatrell, 2013: 8-9). We are not clergy, and some of our interviewees viewed our lack of connection to the CofE positively in that they did not want their views conveyed to those in senior positions within the Church such as their archdeacon or bishop.

Thematic analysis of the interviews was conducted manually with general categories developed initially from the interview agendas themselves, which were then expanded upon and subdivided. In general, while we were aware of highlighting exceptions, we have looked primarily for the existence of shared meanings or 'interpretive repertoires' (Potter, 1996) among the views of the interviewees. Our intention is not to provide analysis that can be generalized across the whole population of CofE clergywomen. We are also aware that we do not have interviews with clergymen with which to directly compare our interview data; however, given the lack of research on clergywomen, we feel that it is important to capture their experiences as a separate group. In this regard we follow Martin's (2003: 593) premise of feminist standpoint theory, that 'accounts of the less powerful offer knowledge of the more powerful'.

Academic research on CofE clergywomen outside theological studies has been limited to a couple of notable survey studies (Bagilhole, 2003, 2006; and Robbins, 2008) and the two examples of qualitative work discussed earlier, notably Peyton and Gatrell (2013) and Page (2011, 2012, 2014). Our study has cross-overs with this body of work; but has some features which differentiate it. Our research was designed specifically to focus on women and to be based within an employment relations paradigm. Bagilhole's (2002, 2003) research has the closest affinities, exploring clergywomen as professional workers within a male-dominated environment. However, her research was based on survey data of a small number of CofE clergywomen, and while this included space for some 'open' answers, it was not designed to yield the level of qualitative detail that is possible in our study. Furthermore, Bagilhole's sample comprised women in senior roles, whereas ours deliberately involved those at parish priest level (at the 'coal face' of clergy work). In addition, it is useful to assess the change or lack of change more than a decade after this research was conducted. The work by Page, and Peyton and Gatrell includes employment-related aspects, but this is neither the focus, nor the underlying analytical framework of these pieces of research.

\section{The clergywomen's experiences of work within the 'sacrificial embrace'}

Here we use our empirical findings to bring the picture of gendered work within the CofE to life. This highlights the difficult position the clergywomen often face, uncovering experiences of sex discrimination and difficulties in meeting expectations of a traditionally male role, at the same time as satisfaction with their work, and the need to follow their calling regardless of the difficulties. 


\section{The centrality of calling to an understanding of clergy work}

Most interviewees stated that they were in an employment relationship with the CofE; however the centrality of vocational calling to their work was talked about by all our interviewees. As Madeleine articulated:

'[the Church] ...in a technical sense they are my employer but actually it's the Almighty isn't it? That's the trouble for all of us because we feel we've got a calling... what it looks like to be God's person in a particular place'

The majority of interviewees had first felt the calling to be ordained early in their lives, and for all between the ages of fourteen and twenty one. However, for a variety of reasons, including that ordained ministry was not allowed for women at the time, they were not able to live out this calling, and therefore for all but two of the interview group, ordained ministry was a fairly late development for them. Ordination had often come at a critical time in their lives, often coinciding with other crisis points. For more than a third of the interview group, this came within three years of marriage break down, divorce or death of their spouse. For many therefore, ordination represented the end of significant life struggle. One side of the story for these women is an immense feeling of relief that they were now doing what they were supposed to do with their lives.

Furthermore all except one interviewee were adamant that they found their work satisfying. This accords with other research indicating high job satisfaction among clergywomen both in the UK (Bagilhole, 2003), and in the US (McDuff, 2001; McDuff and Mueller, 2002). For our interviewees, job autonomy was a particular source of satisfaction, along with making a difference to people's lives and being part of the local community. The key satisfier however was being able to fulfil their calling, as Edith stated:

'... you just have to keep stepping back and seeing the bigger picture and just seeing God and just being faithful to your calling... that's the most amazing thing to be part of, that you can be part of changing the world and just being called'

This is the wider context in which our interviewees evaluate their work experiences, and frames their ability or willingness to resist or challenge discriminatory treatment.

\section{Examples of direct and indirect sex discrimination}

Peyton and Gatrell (2013) highlight some examples of sex discrimination in their study, notably the way that clerical maternity (p70-4), promotion (preferment) (p100) and remuneration for two-clergy couples (p116) had gendered effects. However these are not foregrounded and are largely analysed in terms of what this meant for their vocational commitment. By contrast what emerged clearly from our interviews was the ubiquity of sex discrimination experienced by the clergywomen as a key feature of their work. Without exception, they had all either personally experienced, or had been witness to, disadvantageous treatment of, and/or hostility and opposition to, them as clergywomen. There appears to be little improvement in this since Bagilhole's (2003) study.

Some of this related to past discrimination around gendered ordination selection procedures and training and the way that age, marital status and dependent children determined the opportunities available for women in a way that they indicated was not a consideration for men. For example a requirement for a separate training programme for married women or women with children, or the fact that applicants over 45 years old were (until a relatively recent change in Church policy), deemed to only be eligible for non-stipendiary ordination. For those ordained in 'the first wave', this gender discrimination was starker than for later entrants, for whom formal sex differences within training provision are no longer apparent. However, these 
memories of discriminatory treatment are important in damaging their views of the Church, and making ordination into an even greater personal struggle. As Joan related:

'...in my chapter' there were several objectors to women priests... On the eve of my priesting [2003] the Area Dean said 'We will be thinking of you and praying for you as you become one of us' and a member of the chapter said 'Oh for goodness sake she's not one of us, she's definitely one of them'. Not anybody, not the Area Dean or my training incumbent - nobody challenged him'

The most common example of discriminatory treatment was the refusal of male clergy or parishioners to take communion from them (arguably the activity most central to their job). This was mentioned by thirteen of the interviewees. Other examples included one interviewee having been spat on in a cafe, another being verbally attacked at a training event, and many receiving rude and threatening emails and telephone calls, all with the fact they were women priests being the motivation for the incident. There were also numerous examples of what would be considered in most conventional organisational settings as unacceptable behaviour from both parishioners and clergymen, for example sexist jokes, banter and teasing and inappropriate physical touching. Two interviewees had experienced a parishioner making an overt and unwanted sexual advance. Six interviewees claimed to have been bullied by parishioners, with the fact they were women as the key factor, two examples of which had led to the interviewees resigning from their posts. These latter incidences have to be considered in the context that many of these women are isolated in rural parishes and are particularly vulnerable. The national officer indicated the lack of Church recognition of this was of concern:

'... being aware of the safety issues of women living often in quite isolated places ... we've had just recently a woman who's had a door kicked down. For her own safety she moved out of the diocese and went to stay with a friend. Obviously fearing for her life, let alone anything else. And the bishop then writes a letter saying 'you're not licensed to live outside of your [parish]'

Notably, some of the examples above relate to discriminatory behaviour of parishioners rather than clergy, although there is clearly a relationship between the two. This type of behaviour was frequent, and there seemed to be acceptance of this as an institutional norm, with a feeling from the women in our study that this was just part of their job, in other words, part of their 'sacrifice'. The instances of refusal to take communion, or even the directly abusive behaviour went largely unchallenged and unreported. Indeed the two women who resigned from their posts stated that they did not feel supported by senior clergy in their struggle against what they considered to be bullying behaviour, even when this was formally reported. We discuss this further in the later section regarding ability and willingness to resist.

Other experiences at decision and policy-making meetings (both parishioner contexts such as parish council meetings and clergy contexts such as team meetings and deanery chapters) included being: talked about behind their backs; openly criticised, belittled in public; overly scrutinised; and not being listened to. Rhiannon related how a clergy colleague had patted her on the head at a team meeting:

'...for me it was more like right, this is telling me something about how you feel about me, which when it's your team rector you kind of think I wonder if this is also informing some of the other things, not feeling... quite often I don't feel heard'

Candice expressed the extent to which she was not taken seriously in her role by senior clergy:

\footnotetext{
${ }^{1}$ In this context, the term chapter is used to refer to all of the clergy in a deanery. A deanery is a geographical area in a diocese within which parishes are grouped for pastoral and administrative purposes under the governance of a rural or area dean. 
'it was a real culture shock to move from working in education to moving to working in the Church... the expectation was that I would know my place... and not get above myself. So I went from being very confident about my role and my abilities to being quite kind of puzzled, hurt, angry, confused about the sort of different set of expectations about ... ordination and being a woman... I remember there was a really significant appointment made to one of the parishes... And it was made without consultation and then when I did say what I thought and why I thought it, it was made very clear that that wasn't my place. And just in terms of things like running meetings and agendas and papers... more of a sort of an expectation that instead of contributing to decision making, you're told to get on with it, rather than bringing to decisions the best thinking that was possible,

The existence of the 'theology of the two integrities' exacerbates the situation because it gives people opposed to the ordination of women an official licence to act in a discriminatory way. For example, six interviewees had experience of male clergy explicitly absenting themselves from training courses or meetings because there were ordained women present. Others voiced how clergy who were opposed to women's ordination simply ignored them or refused to communicate with them, as Amanda related:

'...the priest there just didn't talk to me. I would have to contact him every now ... maybe because I had someone who wanted to be baptised who lived in his parish... and he just literally wouldn't reply, wouldn't answer the emails. I sent him emails so there was a bit of distance so he doesn't actually feel he has to physically talk to a woman... But for some reason it was too difficult... there was really just no meeting point at all'

While the Church centrally, and senior clergy within a particular diocese might have an agenda to increase the numbers of women and might be supportive (such as bishops at the stage of a post becoming vacant), such senior support does not always translate to congregational support. There were a number of cases where the interviewees felt that they had been placed in parishes where they were certain to face opposition and thus were made vulnerable. Fiona's example of her parish appointment was typical:

\section{'I had to cope with their [the congregation's] feeling that the bishop had put me in here and that I was the bishop's choice and not their choice... I'm just the sort of the lamb to the slaughter in there really'}

This was the parish from which Fiona eventually resigned due to bullying behaviour and notably where she was succeeded by a male priest. For her and others, the perception was that the common strategy of the Church was to move the person out to another appointment (commonly through resignation) rather than directly address the discriminatory behaviour.

\section{The difficulty of being female in a male vicar's world}

Our interviewees confirmed the prominence and expectation among congregations and some clergymen of the stereotype of the male vicar who had a full time wife, from which they clearly differed, directly recalling Kristeva's work on women's sacrifice as discussed earlier (Hopfl and Matilal, 2007). As Page (2008) finds in her study of male clergy spouses, the entry of ordained women disrupts the traditional model because the male spouse refuses to accept this identity. Her preliminary research indicates that the work that is usually done by the 'wife' is expected to be taken on by the clergywoman in a way it is not expected of clergymen. The dominance of the male 'breadwinner' model of the vicar was problematic for interviewees, particularly for those with dependent children (13) and more so for those who were single mothers (5). Family-life-work clashes, maternity and childcare issues and lack of understanding of the demands of motherhood, were highlighted as serious problems for most of the interviewees, emphasised to an extent that did not have the 
same prominence in Peyton and Gatrell's (2013) study with a gender mixed sample and perhaps because they included relatively few women with children ${ }^{\mathrm{v}}$, (though they do feature one woman's difficult experience of being a pregnant ordinand). One of the youngest and most recently ordained women Rhiannon had taken two periods of maternity leave while in post. Whilst Rhiannon acknowledged that her archdeacon and bishop were in principle supportive of her maternity leave, she received little support from anybody in preparing for her leave, in terms of covering her post or allowing her to scale down her duties as the pregnancy drew on. Similar difficulties around clerical maternity were the experience of clergywomen in Page (2012). Furthermore, Rhiannon's case illustrates the inherent problem that while maternity leave provisions under CT are now, at least on paper, equivalent to those under employment law, she was effectively left without sufficient resources for support in terms of enacting this policy. Guidance notes around leave issues indicate the discretion that is left within the CT system:

Clause 2 (2) of the Directions confers a requirement on office holders 'in consultation with a responsible person or authority' to 'use all reasonable endeavours to make arrangements for the duties of the office to be performed by another person or persons during the period of leave'. This may simply involve a discussion [own italics] with the archdeacon about how best to ensure that cover is provided whilst the office holder is on leave. (Church of England, 2014)

Such a requirement may seem benign enough, however in practice, within the gendered context of the CofE, the ability to have that discussion can clearly prove very difficult for the individuals concerned. Rhiannon's second maternity leave proceeded more smoothly, but only because having learnt from the experience of the first, she took it upon herself to organise everything, including her cover.

\section{Ability to challenge and resist discrimination}

A key finding of Peyton and Gatrell (2013) is that clergy are less likely to resist the demands of their job, because of the centrality of their vocational commitment - that acceptance of 'sacrifice'. Similarly we found that while interviewees indicated deep sadness about the things that happened to them, and they were concerned about the effects on their families and especially children, these were not seen as issues that could easily be challenged. As Amanda stated, '...this is not like many other sorts of employment. There is an element of sacrifice and giving to it'.

What made the situation worse for our interviewees was the lack of support they felt they had. Over half the group indicated that they felt isolated in their ministry. While most could identify who would act as a line manager (most commonly their archdeacon or bishop), and some had extremely good experiences of support from senior clergy, three interviewees stated specifically that they did not know who in the Church they would contact if they had a problem, while four others would only feel able to go to people from their own informal networks. It is important to reiterate the often remote nature of being a parish priest. Indeed less than half of our interviewees worked in team ministries, so most worked alone. Most had more than one church for which they had responsibility, and much of their week was spent travelling large distances and seeing very few people in a work capacity other than their congregations. Interactions with other clergy could be fairly infrequent, and even less so with more senior clergy. Feelings of isolation are also identified by Peyton and Gatrell, (2013: 131) as personal sacrifices of being 'married to the ministry'.

The continued ambiguities within internal procedures also complicate matters. In terms of the lack of sufficient maternity provision discussed by Rhiannon earlier, a possible option open to her would have been to have taken up a grievance (informal or formal), yet given the lack of clear employment hierarchies within the CofE, it is unclear exactly who Rhiannon could have brought a grievance against. Within the context of wider discriminatory treatment (for example accusations of bullying and harassment), looking at the four criteria on which a complaint of misconduct can be made against clergy under the Clergy Discipline 
Measure, discriminatory behaviour could fall within two of them - 'acting in breach of ecclesiastical law' and 'engaging in conduct that is unbecoming or inappropriate'. However discrimination is not specifically mentioned, leaving room for interpretation. Nor is there opportunity to raise a complaint against a nonclergy individual, significant when the number of instances of discriminatory treatment from parishioners have been identified. In the end, most of our interviewees felt they had to deal with issues themselves, ignore them, or resign, as Rebecca stated:

\section{'...If it happens in a parish setting... there is no recourse. There's nothing you can do about it, there is really nothing'}

Furthermore, the theological divisions within the CofE add another layer of complexity to the issue of challenge and resistance. While the majority of interviewees were wholly negative about the Theology of the Two Integrities, most also claimed that in order to act in accordance with their calling and Christian conviction, people opposed to women's ordination should be accepted and accommodated rather than challenged. The view of Veronica was typical:

\section{'there needs to be some provision within the Church for those people who do not accept women priests...I don't share their views but can respect that they hold them, and for the Church to just abandon them... is not being a loving sister or brother in Christ'}

As the debate in 2012 over women bishops indicates, clergywomen themselves may come from theologically conservative backgrounds, and may therefore (implicitly or explicitly) accept the arguments against women's ordination. More than half of the interviewees indicated that they came from an Evangelical or Anglo-Catholic tradition where the most conservative views on this matter are held. Peyton and Gatrell (2013: 96-7) argue that part of the 'sacrificial embrace' involves, a 'personal vocational professionalism' that effectively self-regulates clergy behaviour in accordance with notions of appropriate priestly conduct including that 'what clergy do is governed by who they are'. Thus, a direct challenge to those opposed to them might conflict with their calling and the ways in which they are supposed to conduct themselves. Official guidance on the CT grievance procedure is illuminating here, where reconciliation is a formal part of the process:

It is central to the teaching of Jesus that those who are reconciled to God must be open to being reconciled to those who have offended them or those they have offended. Reconciliation should be the desired outcome. (Church of England, 2009)

A number of campaign groups have existed within the CofE around women's equality including the original Movement for the Ordination of Women (MOW), now superseded by the Women and the Church (WATCH) campaign group and the Group for Rescinding the Act of Synod (GRAS). This indicates that there are people prepared to challenge inequality within the Church. Two interviewees had been very active in MOW, were also active trade unionists and self-identified as feminists. However, in general our group of interviewees were more measured in their views. While almost half identified themselves as 'feminists', most had very strict qualifications on this, commonly around 'not being strident' or 'not with a capital F', while three were very adamant that they were not feminists. They were fairly evenly split between those who had some involvement with, or were supportive of, these campaign groups, and those that were not supportive. More often views were rather ambivalent. In other words, the widespread experience of discrimination does not necessarily lead to strong support of campaigns to try and change things. The most extreme example of sex discrimination had been won to some extent-women can be ordained priests. It was clear that in terms of the personal satisfaction elicited through this, many of the women were very glad to be 
part of the hierarchy they had once thought was impossible. Thus, there was an explicit view from a small minority of our interviewees that they would rather not cause problems.

An obvious alternative support mechanism could be the trade union. However, similar 'non-radical' attitudes are also identified here, even though over half of the interviewees were union members. Three interviewees had made use of the union for help over an issue, two over the security of their fixed term post, and one over a bullying incident. While a substantial part of these issues related to their treatment as women, it does not appear that the union channel is widely used for dealing with discrimination. For example in the three months between October and December 2013, there were 52 calls to the helpline, seven from CofE clergywomen. The most common issues were around poor management, redundancy/dismissal, and bullying, with only one call being an explicit issue of discrimination (Unite, 2014).

Most of our interviewees had clear ideas about what kind of role the union should play, which was in particular not to be 'militant'. Seeing the union as an 'insurance policy' was a common viewpoint, often tinged with a view that a conventional trade union just did not fit the context because the Church should act in the best interests of everyone in it. As these comments by Judith and Rebecca epitomise:

'I think that belonging to a union does have a little bit of a contradiction in terms, in the church in a sense everything is based on trust. By joining a union are you actually saying I don't trust you'

'I suppose I've always hoped that we might be able to establish some kind of professional association. I would feel more comfortable with that'

The national officer reported that the first contact most clergy have with the union is when something has gone wrong and they ring up the helpline, a view that was backed up by the lay representative:

'...people who say ... unions have no place in the Church. That's till something goes wrong... if I'd had a fiver for every time somebody said 'never thought I'd join a union because I thought the Church was something else'

There was a strong view that the Church should be 'better' than conventional organisations and therefore the union should not be needed. Overall what this amounts to is what Prandy et al (1974: 427) would characterise as a lack of a 'unionate' culture within the CofE, i.e. being wholeheartedly committed to the general principles and ideology of trade unionism and willing to use all the powers of the movement. Most of our interviewees, even if in favour of the union in principle, seemed to individualise their involvement, rather than using the union as a space to collectively work for a radical revision in working practices. This is lived out further in the fact that the union has no collective bargaining rights. Despite its role in campaigning for more employment rights such as taking employment tribunal cases and being involved in the wider consultation that led to the introduction of $\mathrm{CT}$, as the national officer states, it concentrates more on providing an individual servicing function, a function that relatively few take up.

\section{Discussion and Conclusion}

Our study of a small group of clergywomen presents a story of continuing sex discrimination and unequal treatment some twenty years after women's ordination was allowed and a decade after Bagilhole's (2003) research. It is important to present their story, in order to provide a way that harmful practices can be challenged, if made visible and named (Acker, 1990). Bagilhole (2003) set out key recommendations for the CofE- changes to recruitment and selection procedures, introduction of family friendly policies and strong codes of practice that indicate and prohibit unacceptable behaviour towards women. A decade on, we would argue that that insufficient progress has been made and that these recommendations still apply. 
While many of the experiences of our interviewees would accord with those of women entering a variety of male-dominated professions, the prevalence of the embodied male within the CofE (Page, 2011), exacerbates the situation for clergywomen. The patriarchal ideologies that underpin gendered organisations and processes (Acker, 1990) and indirectly shape ideas of authority as male, are explicit within the CofE. Unlike the women engineers in Powell at al's study (2009), notwithstanding how difficult the situation may be for them, clergywomen cannot pretend 'to be', or 'be like' men.

While much discriminatory behaviour comes from parishioners, our data clearly implicates the Church, whether through: actions of male clergy themselves; insufficiently robust procedures, policies and practices; lack of response to discriminatory behaviour of parishioners and clergy; and the continuance of, or lack of robust challenge to, a male model of a priest. As potential strategies to challenge this situation, the lack of legal employment rights, the narrow use and belief in the trade union, and little involvement in grassroots campaign groups, means that there is arguably limited space to challenge their unequal treatment. More significantly, we have considered the central place of religious calling at the heart of clergy work and in so doing contribute to expanding the boundaries of conventional employment relations study beyond narrow conceptualisations of paid work. Peyton and Gatrell's conceptual metaphor of the 'sacrificial embrace' (2013: 83) is important in the way that it explains how clergy can endure and accept the difficulties and hardships that characterise clergy life. Our exclusive focus on clergywomen, where the ubiquity of experiences of sex discrimination is highlighted, places the gendered consequences of the 'sacrificial embrace' in stark relief, particularly in terms of lack of space for resistance or challenge. They are 'embodied' as women, and their 'sacrificial embrace' involves dealing with discriminatory treatment and difficulties that come from trying to fit with a male model of what a priest is, something that clergymen do not (a direct link to the notions of sacrifice in the work of Irigaray and Kristeva discussed earlier). The CofE is currently at a new turning point over the place of women, as on 26th January 2015, Libby Lane became the first female bishop to be consecrated in the CofE. While this is a very positive sign of progress in the campaign for equality for women in the CofE, the research findings of our study lead us to question whether such developments will be able to resolve the complex theological divisions and the gendered inequality regime within the CofE that can currently make work so difficult for clergywomen.

In terms of future research, the case of clergywomen exposes difficulties in the application of conventional strategies for women coping with working in male-dominated occupations. Their experiences could usefully be compared with women in other occupations where a sense of calling, vocation or mission is required, to explore how the particular nature of that calling, played out in the particular organisational/occupational context, impacts upon their work experiences and access to conventional mechanisms of employee voice and support. This paper also opens up potential areas of inquiry, for example it would seem useful to unpack how the concept of the 'sacrificial embrace' interacts with concepts and theories of employee voice and silence within the employment relations and organisation studies field. How does vocational commitment specifically affect when and how individuals speak up or remain silent? Additionally, the role and organising strategies of trade unions and other social movement organisations within other work contexts where vocation and calling are relevant would be of interest.

\section{References}

Acker, J. (2006) ‘Inequality Regimes: Gender, Class, and Race in Organizations', Gender \& Society, 20:4 441-464.

Acker, J. (1990) Hierarchies, jobs, bodies: a theory of gendered organizations', Gender and Society, 4, 2, 139-58. 
Archbishops Council (2013) Statistics for Mission 2012: Ministry, London: Archbishops' Council, Research and Statistics, Central Secretariat.

Bagilhole, B. (2002) Women in Non-Traditional Occupations: Challenging Men, Palgrave: Macmillan.

Bagilhole, B. (2003), 'Not a glass ceiling more a lead roof: Experiences of pioneer women priests in the Church of England', Equal Opportunities International, 25: 2, 109-125

Bagilhole, B. (2006) 'Prospects for Change? Structural, Cultural and Action Dimensions of the Careers of Pioneer Women Priests in the Church of England', Gender Work and Organization, 10: 3, 361-377.

Bell, E., Taylor, S., and Driscoll, C. (2012) 'Varieties of organizational soul: The ethics of belief in organizations', Organization, 19: 425-439.

BIS (2013) Trade Union Membership 2012: Statistical Bulletin, May, Department for Business Innovation and Skills, London.

Prandy, K., Stewart, A., and Blackburn, R.M. (1974), “Concepts and measures: the example of unionateness", Sociology, 8, 3 427-446.

Blohm, U. (2005), Religious Traditions and Personal Stories: Women Working as Priests, Ministers and Rabbis. Frankfurt and Main, Peter Lang.

Butler, J. (2006), 'Sex difference as a question of ethics: Alterities of the flesh in Irigaray and Merleau Ponty' in D. Olkowski and G. Weiss (eds.) Feminist interpretations of Maurice Merleau-Ponty, Penn State University Press. 107-126.

Butler, J. (1990) Gender Trouble: Feminism and the Subversion of Identity. London: Routledge.

Butler, J. (1993) Bodies that Matter: On the Discursive Limits of Sex, Routledge: New York.

Central Stipends Authority (2013) $41^{\text {st }}$ Report, Archbishops Council.

Church of England (2009), Grievance Procedure Code of Practice Under Section 8 Ecclesiastical Offices (Terms of Service) Measure 2009.

Church of England (2013a), Guidance on parochial appointments, Annexe B, Equality and Diversity Issues, May.

Church of England (2013b) Clergy Discipline Measure 2003.

Church of England (2014), Common Tenure, www.commontenure.org Accessed 14 June 2014.

Cranmer, F (2012), 'Case law on church employment', Churches'Legislative Advisory Service, Church House: London.

Dowell, S. and J. Williams (1994). Bread, Wine and Women: The Ordination Debate in the Church of England. London, Virago.

Fotaki, M., Metcalfe, B. D. Harding, N. (2014) 'Writing materiality into management and organization studies through and with Luce Irigaray’ Human Relations, 67: 10, 1239-1263.

Furlong, M. (1998), Act of Synod - Act of Folly? London, SCM Press 
Green, A (2011) A Priesthood of Both Sexes: Paying Attention to Difference, London, SPCK

Green, A. (2009) A Theology of Women's Priesthood, London, SPCK.

Hall, D. and Chandler, D (2005), 'Psychological success: When a career is a calling', Journal of Organizational Behaviour, 26: 155-76.

Hopfl, H. and Matilal, S. (2007) "'The lady vanishes": Some thoughts on women and leadership', Journal of Organizational Change Management, 20: 2, 198-208.

Hopfl, H. (2000) 'On being moved', Studies in Cultures, Organizations and Societies, 6, 15-34.

IDS (2011) Incomes Data Service, http://idseye.com/2011/01/18/more-rights-vicar-the-latest-on-clergyemployment-status/ Accessed 24/06/2014

Martin, P. Y. (2003) 'Said and done' versus 'saying and doing': gendering practices, practicing gender at work. Gender \& Society, 17, 3, 342-66.

McDuff, E. (2001), 'The gender paradox in work satisfaction and the protestant clergy', Sociology of Religion, 6: 1, 1-21.

McDuff, E. And Mueller, C (2002), 'Gender differences in the professional orientations of Protestant clergy', Sociological Forum, 17: 3, 465-491.

Page, SJ (2008) 'The construction of masculinities and femininities in the Church of England: The case of the male clergy spouse', Feminist Theology, 17: 1, 31-42.

Page, SJ (2011) 'Negotiating sacred roles: a sociological exploration of priests who are mothers', Feminist Review, 97, 92-109.

Page, S.J. (2012) 'Femmes, méres at prêtres dans l'Église D’Angleterre: Quels sacerdoces', Travail, Genre et Sociétés, Avril, 27: 55-71.

Page, S.J. (2014), The Scrutinized Priest: Women in the Church of England Negotiating Professional and Sacred Clothing Regimes. Gender, Work \& Organization, 21: 295-307.

Peyton, N. and Gatrell, C. (2013) Managing Clergy Lives: Obedience, Sacrifice, Intimacy, Bloomsbury, London.

Potter, J. (1996), Representing Reality: Discourse, Rhetoric and Social Construction, Sage Publications, Powell A. Bagilhole B. and Dainty, A. (2009) How Women Engineers Do and Undo Gender: Consequences for Gender Equality', Gender, Work and Organization, 16: 4, 411-429.

Puwar, N. (2004) Space Invaders: Race, Gender and Bodies Out of Place, Bloomsbury Academic.

Robbins, M. (2008) Clergywomen in the Church of England: A psychological study, Edwin Mellen, New York.

Roberts, C., Robbins, M., Francis, LJ and Hills, P. (2006) 'The ordination of women and the Church of England today: Two integrities but one pattern of decline in membership statistics', Journal of Anglican Studies, 4: 2, pp201-218.

Sullins, L. (2000) 'The stained glass ceiling: Career attainment for women clergy', Sociology of Religion, 61: 3, pp243-266.

Unite (2014) Faith Workers Newsletter, Spring, Unite the Union, London. 
Wajcman, J. (1998) Managing Like a Man: Women and Men in Corporate Management. Cambridge: Polity Press.

Yeng, S. (2014) 'Irigaray's alternative Buddhist practices of the self', Journal of French and Francophone Philosophy, 22: 1, 61-75.

\footnotetext{
' This does not include hospital chaplains who are organised within the Health sector.

ii There are around 800 additional individuals, not included here whose subscriptions have lapsed but are still considered members.

iii The 1992 legislation that allowed women to be ordained made provisions for clergy and parishes that could not in conscience accept the ministry of a woman priest. They could pass resolutions to prevent either a woman presiding at the Eucharist in their parish (Resolution A) or becoming an Incumbent (Resolution B). In addition, parishes and clergy could request the ministry of a bishop who had not participated in any ordinations of women (Resolution C). It allowed for the creation of three Provincial Episcopal Visiting Bishops to minister to those opposed to ordained women.

iv Suggestions are that the ability to request male priests and bishops to look after parishes will be guaranteed by principles set down in a declaration, with disputes ruled on by an independent reviewer. However these are not formal clauses of the legislation, and opponents will have to trust that their views will be considered.

${ }^{\mathrm{v}}$ Peyton and Gatrell (2013: 26) do not detail about whether their three interviewees with children had dependent children at the time of their interview or if there were more interviewees who had dependent children at some point during their ministry.
} 